\title{
A KUVIK [Athene noctua (Scopoli, 1769)] TÁPLÁLKOZÁSÁNAK VIZSGÁLATA A KISKUNSÁGBAN
}

\author{
Hámori Dániel \\ Magyarországi Kuvik Oltalmi Egyesület, 1082 Budapest, Szőlő u. 86., 2/12. \\ Hungarian Little Owl Protecting Public Benefit Association, H-1082, Budapest, Szőlő u. 86., 2/12. \\ e-mail: koeelnokseg@googlegroups.com
}

\begin{abstract}
HÁMORI, D. (2008): THE DIET OF LITTLE OWLS [Athene noctua (Scopoli, 1769)] IN KISKUNSÁG. Hungarian Small Game Bulletin 12: 193-202. http://dx.doi.org/10.17243/mavk.2014.193

The aim of this study was to examine the diet of Little Owls in Kiskunság. According to the results, the diet of the Little Owl in the Upper-Kiskunság region consists of 40 insect (only 27\% of these Scarabeidae) and 21 vertebrate species.

In the study area Little Owls preferred Common Voles (Microtus arvalis), which constituted more then third of their vertebrate prey. Interestingly, amphibians also represented $12 \%$. As for the arthropod diet, the three most numerous species in the samples were Pentodon idiota, Tettigonia viridissima and Melolontha hippocastani, which illustrates that Little Owls have a wide spectrum of preference regarding insects. It is also worth noting that the samples well represent the natural characteristics of the collection area. The analysis also revealed that Little Owls not always rely on Scarabeidaeas a primary food source among insects, since the proportion of Carabidae was equal to that of Scarabeidae (27\%). The Melolonthidae family amounted to $20 \%$.
\end{abstract}

KULCSSZAVAK: kuvik, Athene noctua, táplálkozás, köpetelemzés, Kiskunság

KEY WORDS: Little Owl, nutrition, owl pellet analysis, Kiskunság

\section{BEVEZETÉS}

A kuvik (Athene noctua) hazánk egyik legkevésbé kutatott bagolyfaja. Hazánkban 1920-2013 között mindössze 987 a fellelhető hazai gyürűzési adat. A Közép- és DélEurópában élő kuvik táplálék összetételéröl viszonylag kevés vizsgálati eredmény áll rendelkezésre (BROOKS, 1992; MiKKOLA,1992). A hazai kutatások többségében csak kisemlős-faunisztikai szempontból elemezték táplálékát (MARIÁN ÉS SCHMIDT, 1967; MOLNÁR, 1984; ANDRÉSI ÉS SÓDOR, 1986).

A kuvik nagy elterjedési területe, valamint a változatos vadászati módja miatt, meglehetősen sokféle táplálékot fogyaszt (ANGELICI et al., 1997). Fő táplálékát kisemlösök és gerinctelenek alkotják, ezek mellett madarakat, ritkán kétéltüeket, hüllőket és halakat is zsákmányol (GLUTZ VON BLOTZHEIM \& BAUER, 1980; ANDRÉSI ÉS SÓDOR, 1986). Az egyetlen bagolyfaj, amely növényi táplálékot is fogyaszt (LANSZKI, 2006). Zsákmányát a talajon, vagy faágakon ragadja meg, és egészben nyeli le. A kuvik táplálkozása földrajzi régiótól, élőhelytől és évszaktól függően is eltérő, a rendelkezésre álló „zsákmányállat-készlet” függvényében. Elsősorban változatos vadászati módja miatt táplálékállatai között - Közép- és NyugatEurópában — legalább 25 kisemlős és 60 madárfaj szerepel (SCHMIDT, 1998). GRESCHIK (1911, 1924) vizsgálatai szerint 106 gerinces állat közül 42 mezei pocok volt, ezen kívül erdeiegerek és güzüegér fordult elő nagyobb számban. 
MARIÁN \& SCHMIDT (1967) az Alföld két pontján, Apajpusztán és Szatymazon végzett vizsgálataik során gyüjtött köpetek alapján 825 gerinces zsákmányállat között legalább 11 emlös, 6 madár és egy kétéltü fajt (ásóbéka) mutattak ki. Tíz százalékon felüli értékkel három faj fordult elö: mezei pocok $(63,0 \%)$, erdei egerek $(13,9 \%)$, házi egér $(10,8 \%)$. Pocsaj mellett 1989 júniusában gyüjtött köpetből nem teljesen kifejlett ürge állkapcsa került elő (fogsorhossz 7,0 mm), két mezei pocok mellett (ENDES, 1990). A korábbi magyar leírásokból létezik olyan, mely szerint a kuvik fiatal kacsát fogott meg az udvarban (RÁCZ, 1982). A kuvik nyáron gyüjtött köpeteiben nagyon sok erősen szklerotizált kutikula maradvány bizonyítja, hogy sok rovart zsákmányol, az erre vonatkozó hazai vizsgálatok azonban még hiányoznak (SCHMIDT, 1998).

A 2003-ban megkezdett kiskunsági kuvikvédelmi program részeként - a védelmi tevékenységek, elsősorban mesterséges odúkihelyezések mellett - táplálkozásbiológiai vizsgálatokat is végeztünk. A korábbi adatgyüjtések és azok eredményei mindezidáig nem kerültek teljes értékü publikálásra, ezt a hiányt kívánom jelen tanulmányommal pótolni. A vizsgálatok célja az volt, hogy minél több ismeretet szerezhessünk a felső-kiskunsági kuvik populáció táplálkozási szokásairól. A cél itt elsősorban nem a mintaterület kisemlős- és rovarfaunisztikai feltérképezése, hanem a faj táplálkozási szokásainak, alkalmazkodási képességének vizsgálata volt.

\section{ANYAG ÉS MÓDSZER}

\subsection{Vizsgálati területek}

A 2005 januárjában megkezdett köpetgyüjtések során azt tapasztaltuk, hogy a kuvikok rendszeresen változtatják köpetelő-helyeiket. Egy adott helyen a januári gyüjtés után egy hónappal később már nem lehettünk biztosak abban, hogy ugyanazon a helyen újra megfelelö mennyiségü köpetet találunk. Így az elöre megtervezett gyüjtési stratégiát nem tudtuk megvalósítani, ezért kénytelenek voltunk a gyüjtések helyszíneit a mintaterületen több alkalommal megváltoztatni. Összesen 4 revír- és egyben köpetelö-körzetet jelöltünk ki a területen. Azért is nevezzük körzetnek, mert nem volt minden esetben lehetöségünk arra, hogy az egyes ismert kuvikpárok revírjének központjában (az épületben, ahol fészkeltek) gyüjthessünk mintát. Így például Juhászföld központjában (Bugyi, Ürbőpuszta), egy juhhodály tetőszerkezete alatt fészkelő kuvikpár köpeteit nem csak a hodály tetőszerkezetén, hanem a mellette álló már nem használt libahodályban, és az a szomszédos kis tanyaépületben is gyüjtöttük. A négy kijelölt körzet a következő volt: Petőfi juhhodályok-Apaj (1), Juhászföld-Bugyi (2), 39-es odú-Kunpeszér (3), 57-es odú-Ladánybene (4). Ezekben a körzetekben összességében 11 helyről gyüjtöttünk köpeteket (1. táblázat)

A Petőfi juhhodályok körzetében (Apaj) azok tetőszerkezetéről, az épület mellett álló odúból (ahova a kuvikok tavaszig bejártak), valamint magából a hodály tetőszerkezete alatti fészekaljzatból gyüjtöttünk anyagot. Juhászföldön (Bugyi, Ürbőpuszta) a már példaként említett helyszínekről történt a gyüjtés. A 39-es és 57-es odú esetében (ahol kuvikfészkelés volt) a fiókák kirepülése után történt meg a mintavétel oly módon, hogy a fiókák és esetlegesen a szülők által az odúban felhalmozott teljes anyagot begyüjtöttük (az előbb említett Petőfi juhhodályban lévő odúaljzatából is hasonlóképpen a teljes felhalmozott anyagot összegyüjtöttük). Gyüjtéseink közül ezek a legteljesebbek, hiszen ezek a fiókák kikelésétől az odúból történő kirepülésig az összes, a fiókák, és részben a szülők által fogyasztott zsákmányállatmaradványokat tartalmazták. További előnye ezen anyagoknak, hogy nem csak a köpetekben lévő zsákmányállat-maradványok elemzésére, hanem az odúban csak széttépett, de egészében le nem nyelt zsákmányállat-maradványok meghatározására is sor kerülhetett. 
1. táblázat: A gyüjtött kuvik köpetanyagok összesítő táblázata

Table 1: Sampling sites and characteristics of the collected Little Owl pellets

\begin{tabular}{|c|l|c|c|c|}
\hline $\begin{array}{c}\text { Körzet } \\
\text { Site }\end{array}$ & \multicolumn{1}{|c|}{$\begin{array}{c}\text { Pontos helyszín } \\
\text { Location }\end{array}$} & $\begin{array}{c}\text { Gyüjtések száma } \\
\text { Number of } \\
\text { collection }\end{array}$ & $\begin{array}{c}\text { Gyüjtés időpontja } \\
\text { Date of collection }\end{array}$ & $\begin{array}{c}\text { Gyüjtött köpetek száma } \\
\text { Number of collected pellets }\end{array}$ \\
\hline \multirow{3}{*}{1} & Tetőszerkezet & 1 & 2005.02 .03 & 12 \\
\cline { 2 - 5 } & Hodály melletti téglatestes odú & 2 & $05.01 .12 . ; 05.03 .23$. & 23 \\
\cline { 2 - 5 } & Tetöszerkezet alatti fészekalj & 1 & 2005.09 .01 & $\begin{array}{l}\text { fészekaljban felhalmozott teljes } \\
\text { anyag }\end{array}$ \\
\hline \multirow{2}{*}{2} & Birkahodály tetőszerkezete & 1 & 2005.02 .07 & 16 \\
\cline { 2 - 5 } & Hátsó sárga libahodály & 3 & $02.03 . ; 03.23 . ; 07.15$. & 13 \\
\cline { 2 - 5 } & Lengyel-tanya & 1 & 2005.07 .13 & $\begin{array}{l}\text { fészekaljban felhalmozott teljes } \\
\text { anyag }\end{array}$ \\
\hline \multirow{2}{*}{3} & $\begin{array}{l}\text { Kihelyezett kuvikodúban } \\
\text { felhalmozott anyag }\end{array}$ & 1 & 2005.09 .01 & $\begin{array}{l}\text { fészekaljban felhalmozott teljes } \\
\text { anyag }\end{array}$ \\
\hline \multirow{2}{*}{4} & $\begin{array}{l}\text { Kihelyezett kuvikodúban } \\
\text { felhalmozott anyag }\end{array}$ & 1 & 2005.09 .01 & \\
\hline
\end{tabular}

A következőkben ezen teljes körüen elemzett három helyszínt - ahol a fiókák kirepülése után a teljes, a fészekaljzatban felhalmozott anyagot összegyüjtöttük - mutatom be.

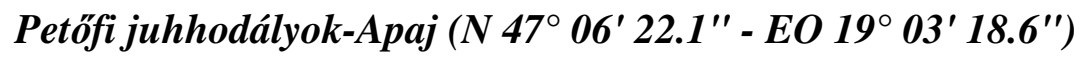

A fészek egy juhhodály tetőszerkezete alatt volt megtalálható. A revír itt igen mozaikos. Elsősorban birkalegelőkből és intenzív mezőgazdasági területekből áll, de a müködő birkahodály-együttes mellett van egy idősebb kocsányos tölgy fasor, valamint egy ritkás elegyes ligetszerü erdőfolt. A legelők mellett kisebb, időszakonként kaszált gyepfoltok, valamint az azokat átszelő csatornák, időszakos vízfoltok jellemzik a területet. Kirepült fiókák száma: 4(3)

\section{9-es odú-Kunpeszér $\left(47^{\circ} 04.862 \mathrm{~N} ; 019^{\circ} 14.758 \mathrm{E}\right)$}

A kihelyezett mesterséges odú - amiben a költés lezajlott - környezetére az állattartó (főleg szarvasmarha, juh, valamint liba) épületek sokasága a jellemző. Ezen a területen igen nagy a legelö-, valamint a folyamatosan kaszált gyepterületek aránya. Szikes foltokkal itt csak ritkán találkozhatunk, de ezeken rendszeresen előfordulnak kisebb megrekedő vízfoltok. A kisebb útszéli akác, nyár, valamint fenyőfoltokkal tarkított területet csak egy nagyobb csatorna szeli át. Kirepült fiókák száma: 6 (5).

\section{7-es odú-Ladánybene $\left(47^{\circ} 04.928 \mathrm{~N} ; 019^{\circ} 20.989 \mathrm{E}\right)$}

Ez a hengertestes odú Ladánybene település közelében található egy már lakatlan épület előtti öreg tölgyfán. A területet a tanyasi nyaraló épületek sokasága jellemzi, így környezetét tekintve az előző mintavételi helyszínektől jelentősen eltér. Az épületek többsége itt csak időszakosan lakott, az állattartás ezen a területen csekély mértékü. Ennek köszönhetően legelök, kaszálók itt alig vannak. Jellemzőbbek viszont a parlagon hagyott, aranyvessző (Solidago spp.) által benőtt területek, valamint a fehér akác-, nemesnyár- és feketefenyő ültetvények. Kirepült fiókák száma: 6 (7). 


\subsection{A köpetelemzés menete}

A kuvik köpetek is alkalmasak táplálékának vizsgálatára. Köpetei a legkülönbözőbb helyeken találhatók attól függően, hogy a bagoly egy elhagyott juhhodályban, odvas fában, mesterséges költőládában, vagy épületek romos részein ütötte fel tanyáját. A kuvik egyike azoknak a bagolyfajoknak mely a fénytöl kevésbé idegenkedik, ezért nappal is könnyen megfigyelhetjük háztetökön, kéményeken. E miatt viszont köpetei is elég elszórtan hevernek, és maradéktalan összegyüjtésük gyakorlatilag szinte lehetetlen (pl. hodály palatetős tetöszerkezete alá beesett köpetek sok esetben hozzáférhetetlenek).

A gyüjtés után a köpeteket már a helyszínen dobozokba helyeztük, majd megcímkéztuik és lezártuk őket. A címkére ráírtuk a gyüjtés, pontos helyét, időpontját, valamint a köpetek számát.

Ezután az egyes köpetanyagokat nem köpetenként, hanem egészét tekintve vizsgáltam. Ez természetesen nem azt jelenti, hogy az egyes anyagokat ömlesztve boncoltam, hiszen magát a bontást és szétválogatást mindig köpetenként végeztem. Egy bizonyos anyagból tehát egy köpetet kivettem, azt fertőtlenítős vízzel leszórtam (elsősorban azért, hogy a köpet szétszedésekor a por ne szálljon annyira szét), majd óvatosan szétszedtem. A köpetben talált gerinces maradványok közül a mandibulák-at és maxillák-at, a rovarmaradványokból pedig a fej, tor, potroh, láb, szárny, szárnyfedő, szájszerv, ivarszerv és egyéb darabokat külön-külön tettem edénybe, majd megcímkéztem ezeket. Az egyes köpetek vizsgálata során több alkalommal találkoztam meghatározhatatlan mandibulák-kal, illetve maxillák-kal, amelyeket a köpetelemzések során külön feljegyeztem. Azokban az esetekben, amikor az elemzésre váró anyagok a fészekaljakban felhalmozott táplálékmaradványok voltak, az elemzés menete másképpen zajlott. E három esetben ugyanis ép köpeteket csak ritkán találtam, többségében ezeket a fiókák már összetaposták, így az anyagból kigyüjtött elemzésre váró darabok jelentős része csak nehezen, vagy egyáltalán nem volt határozható. A szétválogatást követően az egyes anyagokat külön kezeltem. A köpetanyagok (és egyéb zsákmányállat-maradványok) szétbontogatása után a mandibulák-at és maxillák-at (valamint egyéb határozásra alkalmas madár, kétéltü, hüllő maradványokat) tartalmazó anyagokat fehérítős vízbe beáztattam, majd óvatosan átöblítettem, ügyelve arra, hogy az elemzésre váró részek ne sérüljenek, így előkésztettem azokat a határozásra. Az öblítés után nedvszívó papírra rendeztem az egyes mintákat, majd azok szárítása után az egyes kisemlős-családok, valamint a madarak, kétéltűek-hüllők szerint, egyenként szortíroztam azokat. A köpetbontás, áztatás, öblítés, szárítás, majd szortírozás után a gerincesek elemzésre váró maradványaiból a következő csoportokat alakítottam ki: egérfélék (Muridae), pocokfélék (Microtinae), cickányfélék (Soricidae), énekesmadarak (Passeriformes), kétéltűek (Amphibia), hüllők (Reptilia) különkülön fiolába kerültek. A köpetbontások folyamán előkerült és kiválogatott rovarmaradványokat tovább már nem kezeltem, illetve válogattam. Az egyes szortírozott gerinces csontmaradványokat sztereomikroszkóp segítségével, általában 15,75 x vagy 25,2 xes nagyítás alatt vizsgáltam.

Nem csak a jobb és bal mandibula-k, valamint az egyes maxilla-k számát vizsgáltam, hanem lehetőség szerint (amennyiben a vizsgált darab erre alkalmas volt) az alsó és felső fogsorhosszt, a koponya legnagyobb szélességét, valamint az interorbitális szélességet is lemértem és az adatbázisba feljegyeztem. A köpetanyagokban talált adott fajhoz tartozó meghatározott csontmaradványok közül mindig csak a legmagasabb darabszámú csonttípust vettem figyelembe. Az egyes anyagokban talált zsákmányállat-fajok egyedszámát ezen metodika alapján állapítottam meg (például egy gyüjtött köpetanyagban talált 12 ásóbéka (Pelobates fuscus) koponya, valamint 17 fronto-parietale esetében tehát az anyagban megállapított ásóbékák száma 17 lett). 
A kuvik nyáron gyüjtött köpeteiben nagyon sok erősen szklerotizált kutikula maradvány bizonyítja, hogy sok rovart zsákmányol, az erre vonatkozó hazai vizsgálatok azonban még hiányoznak. Ezt a hiányosságot szándékoztunk részben pótolni a rovartáplálék elemzésével. Mivel a gyüjtött anyagok többszöri átvizsgálására is sor került, így a teljes, határozásra alkalmas rovarmaradványokat sikerült az egyes vizsgálati anyagokból kiemelnünk. A köpetbontások során fellelt maradványokat köpetanyagonként külön fiolákba helyeztük. A legjobban határozható, vagy legjobb állapotban megmaradt anyagokat nem a köpetbontások során fellelt, hanem a fészekaljakból gyüjtött zsákmányállat-maradványok között találtuk, hiszen itt az egyes elfogyasztott rovarok széttépett darabjai is a rendelkezésünkre álltak, melyek többségükben még kellö biztonsággal határozható állapotban voltak. A három körzet teljes gyüjtési anyagának a részletes vizsgálata megtörtént. Az elemzések során az egyes fajokhoz tartozó testrészekről digitális fényképeket készítettünk, ezzel is segítve a későbbi határozásokat.

\section{EREDMÉNYEK ÉS MEGVITATÁS}

\subsection{A köpetanalízis eredményei - gerincesek}

A gyüjtött 11 anyagban összesen 361 gerinces zsákmányállat-egyedet határoztam meg. A kijelölt 4 körzetben 2005. január-augusztus között gyüjtött minták elemzése alapján a következő eredményeket kaptam (1. ábra).

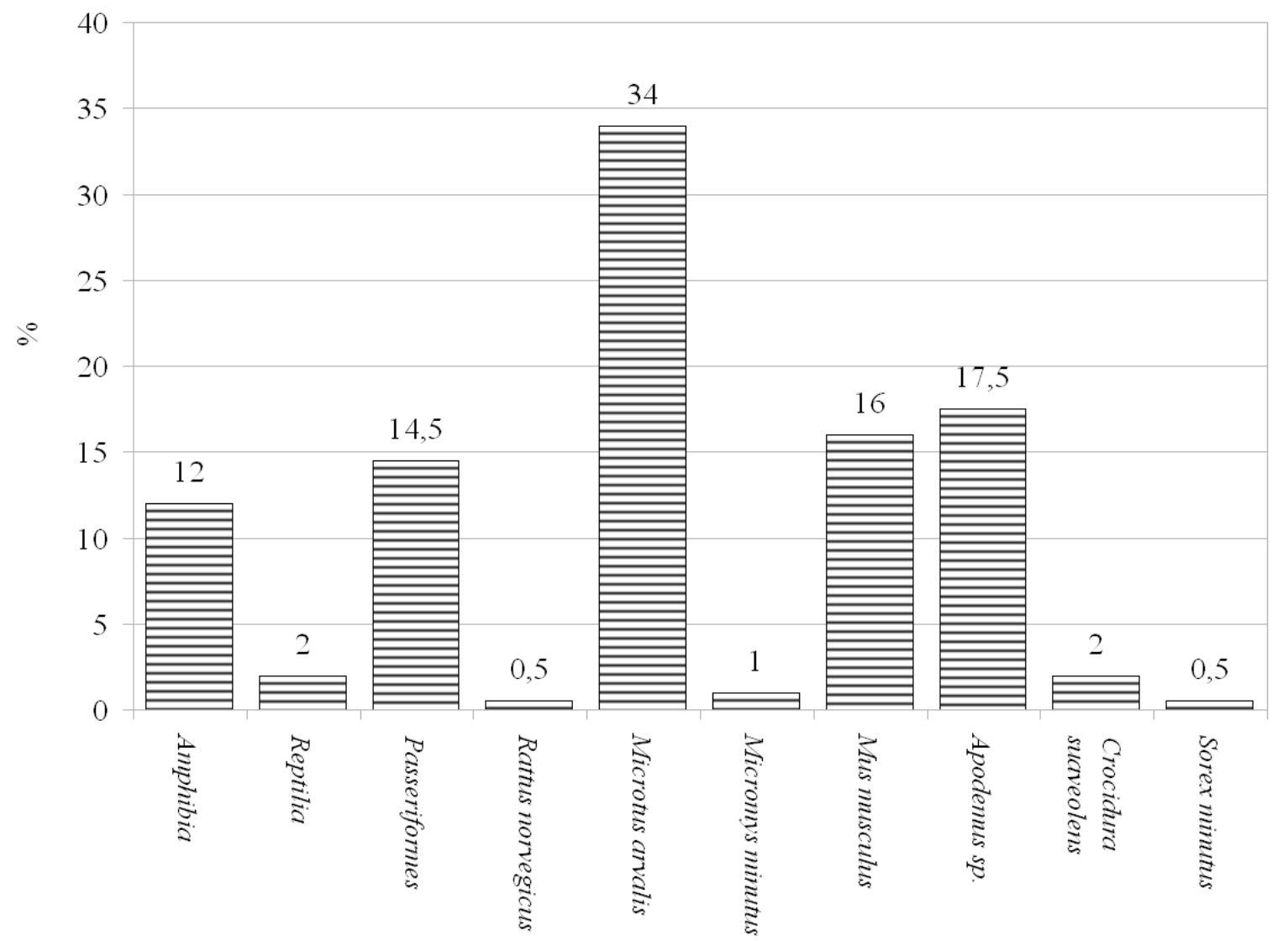

1. ábra: A kuvik gerinces zsákmányállatainak százalékos megoszlása (Felső-Kiskunság, 2005. január-augusztus; 361 meghatározott egyed)

Figure 1. Proportion of vertebrate diet of Little Owls (Felső-Kiskunság, period January-August 2005; 361 prey individuals) 
$\mathrm{Az}$ egyes meghatározott fajok, illetve egyéb zsákmányállat-csoportok alapján egyértelmüen látszik, hogy a vizsgált területen a kuvikok a mezei pockokat (Microtus arvalis) részesítették előnyben. Az elfogyasztott zsákmányállatok több mint harmadát e faj egyedei tették ki a mintaterületen. A további négy, $10 \%$ fölötti értéket adó faj, illetve állatcsoport a következő: 17, 5 \%-al az Apodemus fajok (elsősorban az Apodemus sylvaticus), $16 \%$-al a házi egerek (Mus musculus), 14,5 \%-al az énekesmadarak (Passeridae), valamint $12 \%$-al a kétéltüek (Amphibia) szerepeltek. Az Abodemus-fajok nagy száma valószínüleg a gyüjtési helyek közvetlen közelében elhelyezkedő telepített erdőknek, illetve a bokros területeknek köszönhető.

A hodály- és más tanyasi épületek közvetlen közelében egész évben kiváló életkörülményeket találnak maguknak a házi egerek, amelyek így folyamatos táplálékforrást biztosítanak a kuvikoknak. A magas énekesmadár-fogyasztás (első sorban házi- és mezei veréb) is hasonlóképpen magyarázható. A tanyavilág lakott létesítményeinél szinte mindig találkozhatunk házi- és haszonállatokkal, amelyek takarmányát az énekesmadarak is rendszeresen fogyasztják. Ennek köszönhető, hogy a tanyasi épületek környezetében folyamatosan jelen vannak kisebb-nagyobb verébcsapatok, melyek kiváló kiegészítő táplálékforrást jelentenek a kuvikok számára. Az ásóbékák magas aránya azzal magyarázható, hogy ez a faj éjszaka a talajon mozog, és így könnyü prédájává válik a kuviknak. Tapasztalataim szerint ugyanis, ha az egyes fészekaljakból vett táplálékmaradvány-minták esetében csak a köpeteket vizsgáltam volna, akkor a fent bemutatott diagramon a kétéltüek aránya valószínüleg még a 3\%-ot sem érte volna el. Ezek alapján tehát úgy gondolom, hogy a zsákmányként fogott békák többségét a fiókák nem teljes egészében fogyasztották el, hanem csak megtépték azokat. A kuvikok hüllö-, cickány-, valamint vándorpatkány fogyasztása az eddig elvégzett hazai kiértékelésekhez viszonyítva nem mutat nagy eltéréseket.

A Petőfi juhhodályok (Apaj) egyikében költő fészekaljban, valamint a 39. és 57. sz. odúkban, májustól augusztusig terjedő időszakban (elsősorban a fiókák által) felhalmozott csontmaradványok alapján e három, környezeti jellemzőiben eltérő helyszínek táplálkozási eredményeit hasonlítottam össze és összegeztem (2. ábra).

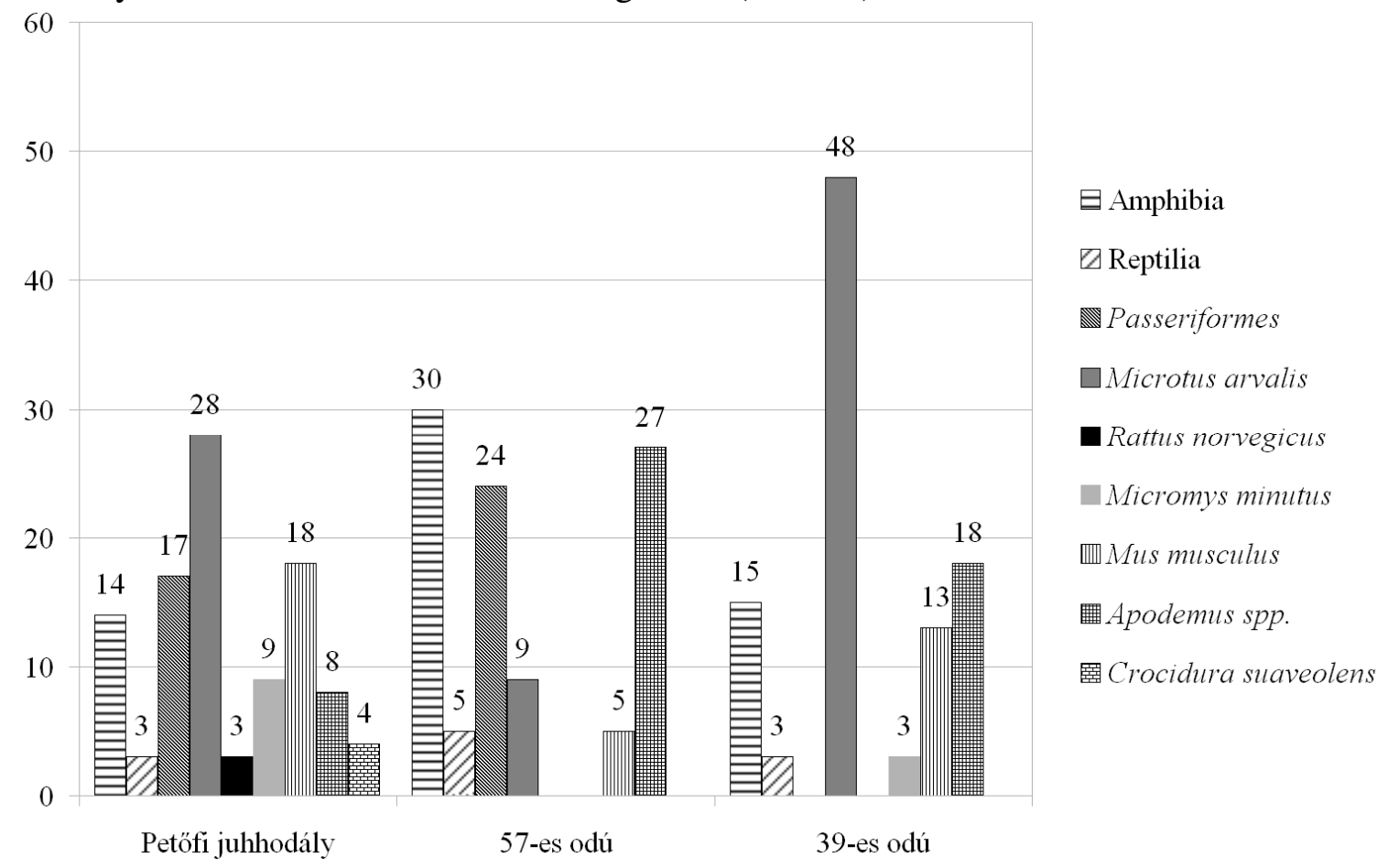

2. ábra: Fészekaljakban felhalmozott zsákmányállat-maradványok taxononkénti megoszlása az egyes költőhelyeken

Figure 2. Proportion of prey remnants found in the nests in the studied sites 
A diagramból jól kitünik a kuvik egyes területeken való táplálékspecializálódása. A kétéltüek esetében 30 \%-os (a többi helyszínhez képest kétszeres) értéket az 57. sz. odú esetében tapasztalhatunk. Ez a már bemutatott környezeti feltételekkel, azaz a sürün épített pincés nyaralókkal (ásóbékák kiváló „,rejtekhelyei”), valamint a telepített erdők és kezeletlen területek nagy arányával, az ennek köszönhető vélhetően alacsony kisemlős-állománnyal magyarázható.

Mezei pockokat $48 \%$-os arányban a 39. sz. odúban költő család fogyasztott. Ez a nagy legelö-, valamint folyamatosan kaszált gyepterületeknek, a Petőfi juhhodályok fészekaljának esetében kapott $28 \%$-os érték pedig a jelentős nagyságú birkalegelőknek tudható be. A házi egerek 18\%-os arányban estek áldozatul a kuvikoknak a Petőfi juhhodályoknál, minden bizonnyal a folyamatos állattartásnak és az azok téli táplálásához szükséges takarmánytárolóknak, trágyalerakatoknak köszönhetően. Az Abodemus-fajok fogyasztása is az 57. sz. odú esetében volt jelentős $(27 \%)$ a már említett telepített erdőknek, valamint a parlagon hagyott élőhelyeknek köszönhetően. A többi faj egyedeinek elejtésére csak egy-egy estben került sor.

\subsection{A köpetanalízis eredményei - ízeltlábúak}

Az egyes köpetanyagokban meghatározott rovarfajokat a 2. táblázatban foglalom össze.

2. táblázat: A vizsgált körzetek kuvik-köpetanyagából meghatározott ízeltlábúak

Table 2. Arthropods identifeid in Little Owl pellets collected in the study sites

\begin{tabular}{|c|c|c|c|}
\hline & Petőfi juhhodályok & 39. sz. odú & 57. sz. odú \\
\hline BOGARAK - COLEOPTERA & 33 & 34 & 34 \\
\hline Csíkbogárfélék (Dytiscidae) & 1 & & \\
\hline Dytiscus marginalis & 1 & & \\
\hline Futóbogárfélék (Carabidae) & 8 & 12 & 7 \\
\hline Amara aenea & & 2 & \\
\hline Anisodactylus binotatus & & & 2 \\
\hline Broscus cephalotes & & 2 & \\
\hline Calathus fuscipes & & 1 & \\
\hline Calosoma auropunctatum & & & 1 \\
\hline Calosoma sycophanta & & 3 & \\
\hline Harpalus affinis & 1 & & \\
\hline Harpalus distinguendus & 2 & 1 & \\
\hline Harpalus hirtipes & & 1 & \\
\hline Harpalus tardus & 2 & 2 & \\
\hline Harpalus sp. & 3 & & \\
\hline Poecilus cupreus & & & 1 \\
\hline Zabrus spinipes & & & 3 \\
\hline Dögbogárfélék (Silphidae) & & 2 & 1 \\
\hline Silpha carinata & & 2 & 1 \\
\hline Szarvasbogárfélék (Lucanidae) & & 3 & \\
\hline Dorcus parallelepipedus & & 3 & \\
\hline Sutabogárfélék (Histeridae) & 2 & & \\
\hline Paralister purpurascens & 2 & & \\
\hline Álganajtúró-félék (Geotrupidae) & 1 & 1 & \\
\hline Geotrupes spiniger & 1 & & \\
\hline Odonteus armiger & & 1 & \\
\hline
\end{tabular}




\section{A 2. táblázat folytatása}

Table 2. continued

\begin{tabular}{|c|c|c|c|}
\hline & Petőfi juhhodályok & 39. sz. odú & 57. sz. odú \\
\hline Ganéjtúrófélék (Scarabaeidae) & 18 & 6 & 3 \\
\hline Aphodius prodromus & 1 & & \\
\hline Aphodius sp. & 2 & & \\
\hline Copris lunaris & 3 & 3 & 1 \\
\hline Oryctes nasicornis & & 3 & 2 \\
\hline Pentodon idiota & 12 & & \\
\hline Cserebogárfélék (Melolonthidae) & & & 20 \\
\hline Melolontha hippocastani & & & 20 \\
\hline Gyászbogárfélék (Tenebrionidae) & 1 & & \\
\hline Tenebrio molitor & 1 & & \\
\hline Levélbogárfélék (Chrysomelidae) & 1 & 2 & \\
\hline Phytodecta fornicata & 1 & & \\
\hline Oulema melanopa & & 2 & \\
\hline Virágbogárfélék (Cetoniidae) & & 3 & 2 \\
\hline Cetonia aurata & & 1 & 1 \\
\hline Potosia aeruginosa & & 1 & 1 \\
\hline Potosia cuprea & & 1 & \\
\hline Szipolyfélék (Rutelidae) & & 1 & \\
\hline Anomala vitis & & 1 & \\
\hline Pattanóbogár-félék (Elateridae) & & 2 & \\
\hline Agrypnus murinus & & 1 & \\
\hline Melanotus punctolineatus & & 1 & \\
\hline Cincérfélék (Cerambycidae) & & 1 & \\
\hline Plagionotus floralis & & 1 & \\
\hline Ormányosbogár-félék (Curculionidae) & 1 & 1 & 1 \\
\hline Otiorhynchus ligustici & & 1 & \\
\hline Psalidium maxillosum & 1 & & 1 \\
\hline EGYENESSZÁRNYÚAK (ORTHOPTERA) & 12 & 15 & 2 \\
\hline Gryllotalpa vulgaris & 6 & & 1 \\
\hline Gryllus campestris & 1 & 1 & \\
\hline Tettigonia viridissima & 5 & 14 & 1 \\
\hline
\end{tabular}

A 3 vizsgált anyagban a legnagyobb egyedszámban kimutatott rovarfaj a Pentodon idiota, a Tettigonia viridissima, valamint a Melolontha hippocastani volt, melyek jól jellemzik a kuvik széles rovartáplálék spektrumát. Az elemzett anyagokban meghatározott fajok megfelelően tükrözik az adott köpetgyüjtési körzet természeti adottságait (pl. lótetü a Petőfi juhhodályoknál; gabonafutrinka, ganéjbogár, aranyos bábrabló a 39-es odú esetében; zömökfutrinka, gyalogormányos az 57-es odú esetében).

A hazai források szerint a kuvik nyáron sok rovart zsákmányol, amelyek túlnyomó többsége a ganajtúrófélék (Scarabeidae) családjába tartozik (SCHMIDT, 1998). A vizsgálataink alapján megállapítottuk, hogy a kuvik nem minden élőhelyen használja ki ezt a táplálékforrást. A bogarak rendjére vonatkozó elemzéseket és kiértékeléseket összesítő diagramból (3. ábra) kitünik, hogy a Scarabeidae család tagjainak zsákmányul ejtésével teljesen azonos mértékü volt a Futóbogárfélék (Carabidae) család fajainak fogyasztása is (27$27 \%$ ). E mellett $20 \%$-os arányt ért el a Cserebogárfélék (Melolonthidae) aránya is.

Összességében tehát megállapítható, hogy a gyüjtött minták alapján a Scarabeidae család képviselői csak a kuvik által fogyasztott rovaregyedek mintegy harmadát teszik ki a gyüjtött és elemzett minták alapján. 


目 Carabidae
$\square$ Scarabeidae
$\mathbb{N}$ Lucanidae
$\square$ Curculionidae
$\mathbb{W}$ Silphidea
$\mathbb{Z}$ Cetoniidae
$\square$ Melolonthidae

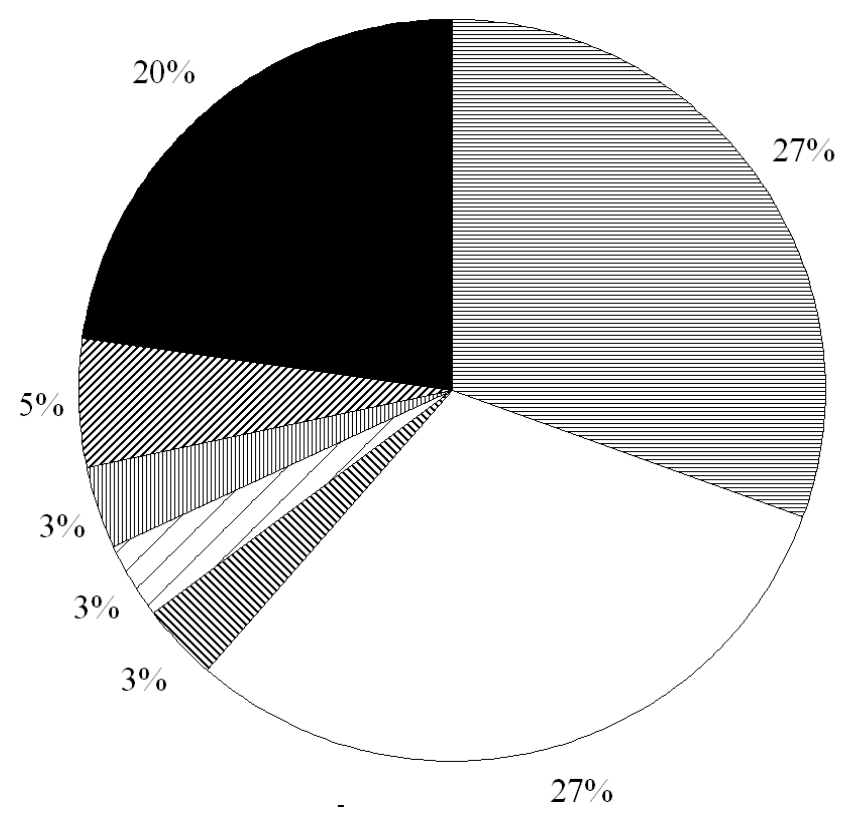

\section{3. ábra: A Coleoptera rend családok szerinti összesített megoszlása az elemzett táplálékmaradványok alapján}

Figure 3. Proportion of Coleoptera families based on the total prey remnant material analyzed

Az Orthoptera renden belül - a csekély fajszámnak köszönhetően - kizárólag faji szintü elkülönítést tettünk. Az Orthoptera renden belüli zsákmányfajok közül 68 \%-os arányban a Tettigonia viridissima, 24 \%-os mértékben a Gryllotalpa vulgaris szerepel (4. ábra). E két faj is jól jellemzi a kuvik kedvelt vadászterületeit, a legelőket és a Kiskunságban elsősorban a juhokat tartó telepeket.

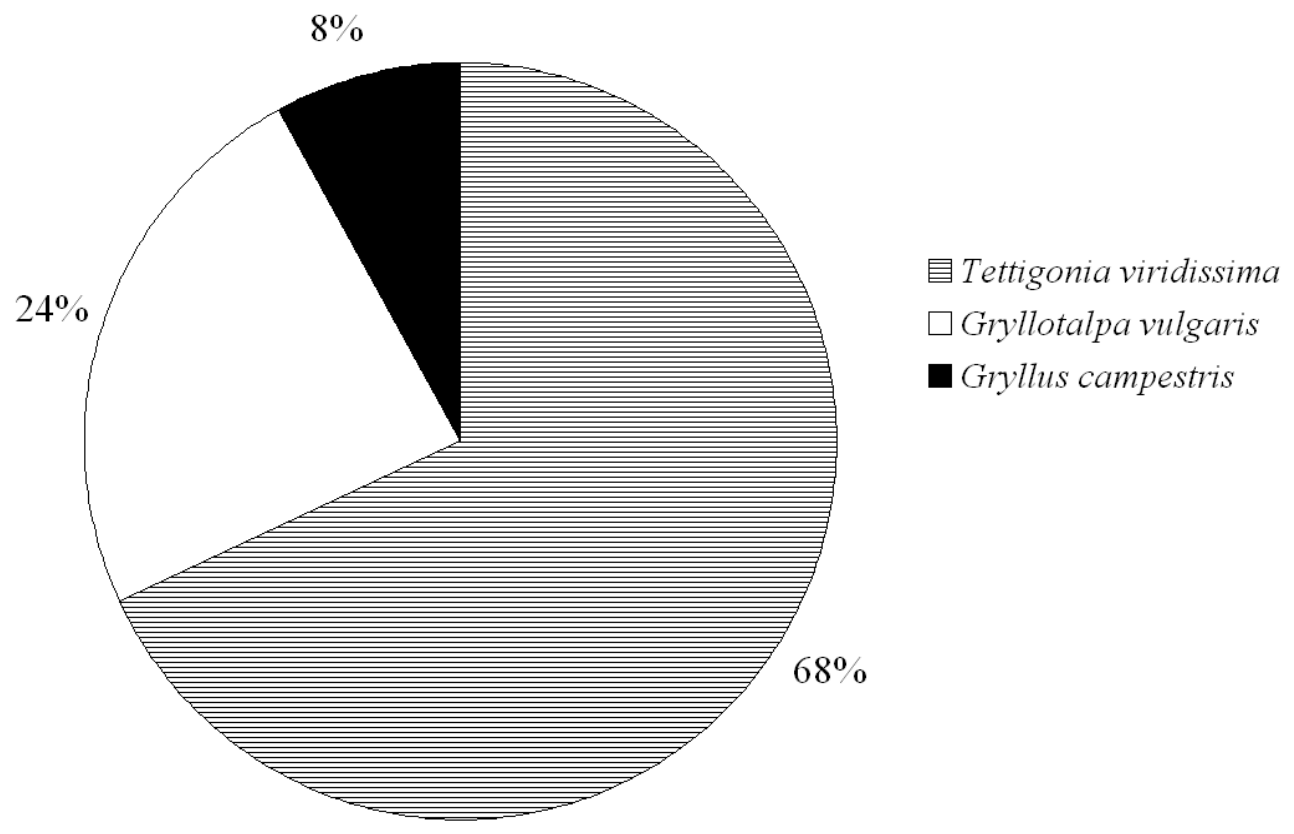

\section{4. ábra: Az Orthoptera rend faj szerinti összesített megoszlása az elemzett táplálékmaradványok alapján}

Figure 4. Proportion of Orthoptera species based on the total prey remnant material analyzed 


\section{4. ÖSSZEFOGLALÁS}

Az elvégzett elemzések alapján a Coleoptera renden belül 37, az Orthoptera renden belül 3 faj, azaz összesen 40 rovarfaj került elő a táplálékmintákból. A gerincesekre és gerinctelenekre vonatkozó vizsgálataim szerint a mintaterületen élő kuvikok táplálékspektrumát - a gyüjtött és elemzett 3 revírterület mintaanyaga alapján hozzávetőlegesen tehát 40 rovar és 21 gerinces állatfaj alkotja. A kuvik táplálék-összetétele tehát attól függően alakul, hogy a revírjében milyen típusú élőhelyek találhatók, illetve hogyan alakul a földhasználat. Mindezek alapján megállapítható, hogy a kuvik táplálkozási szokásai nem merevek, hanem képes az adott élöhelynek megfelelö zsákmányállat-fajok kínálatához rugalmasan alkalmazkodni, ezáltal a faj túlélő képessége is „fejlettebb” más hazai bagolyfajokhoz (pl. gyöngybagoly) képest.

\section{KÖSZÖNETNYILVÁNÍTÁS}

Hálásan köszönöm DR. TRASER GYÖRGY útmutatásait, valamint a rovartani elemzésekben nyújtott segítségét, DR. SzÉL GYŐzŐ rovarok meghatározásában nyújtott segítségét, illetve DR. LANSZKI JÓZSEFNEK a köpetelemzésekkel kapcsolatos tanácsait, valamint a MAGYARORSZÁGI KUVIK OLTALMI EgYESÜLET tagjainak terepi munkáját és segítségét!

\section{IRODALOMJEGYZÉK}

ANDRÉSI P. \& SÓDOR M. (1986): Adatok fészkelő bagolyfajaink táplálkozásökológiájához. A Magyar Madártani Egyesület II. Tudományos Ülése, Szeged. p. 293-300.

ANGelici, F.M., LATElla, L., Luiselli, L. \& RigA, F. (1997): The summer diet of the Little Owl (Athene noctua) on the Island of Astipalaia (Dodecanese, Greece). Journal of Raptor Research 3: $280-282$.

Brooks, D. J. /ed./ (1992): Handbook of the birds of Europe the middle East and North Africa. Oxford, p. 514-525.

ENDES M. (1990): Kuvik (Athene noctua) ürgefogyasztása. Calandrella 4(1): 85.

GlutZ von Blotzheim, U. \& BAUeR, K. (1980): Handbuch der Vögel Mitteleuropas, Band 9. Wiesbaden, p. 242-245.

GRESCHIK J. (1911): Hazai ragadozó madaraink gyomor és köpettartalom-vizsgálata II. Baglyok. Aquila 18(1-4): 141-149.

GRESCHIK J. (1924): Gyomor és köpettartalom vizsgálatok. Adatok hazánk apró emlöseinek faunájához. Aquila, 30-31. 243-263.

SCHMIDT E. (1998): Kuvik. In HARASZTHY L. szerk: Magyarország madarai. Mezőgazda Kiadó, Budapest, p. 218-219.

LANSZKI J. (2006): A kuvik (Athene noctua) táplálék-összetétele egy Somogy megyei külvárosi élöhelyen. Natura Somogyiensis 9: 315-324.

MARIÁN M. \& SCHMIDT E. (1967): Adatok a kuvik (Athene noctua [Scop.]) gerinces táplálékának ismeretéhez Magyarországon. Móra Ferenc Múzeum Évkönyve, 1966. 1. sz., p. 271-275.

Mikkola H. (1992): Owls of Europe. T \& A D Poyser, London, p. 397.

MOLNÁr I. (1984): Bagolytáplálkozási adatok a Dunántúlról. Madártani Tájékoztató, 1983-84., p. 110.

RÁCZ B. (1928): A kuvik, mint baromfipusztító. Aquila 34-35: 412. 